\title{
How to do depends on where it settles: Mediastinal parathyroid adenomas
}

\author{
Nasıl yapacağın nerede yerlesstiğine bağlıdır: Mediastinal paratiroid adenomları \\ Hakan Işık $₫$, Merve Şengül İnan 1 \\ Department of Thoracic Surgery, Gülhane Training and Research Hospital, Ankara, Turkey
}

\begin{abstract}
Background: In this study, we aimed to evaluate demographic characteristics, preoperative adenoma localization, surgical techniques selected according to the size and localization of adenoma, and clinical results of patients undergoing mediastinal parathyroid adenoma excision.

Methods: Medical records of a total of 11 patients (4 males, 7 females; mean age 52.6 years; range, 25 to 65 years) who underwent excision of mediastinal parathyroid adenoma in our clinic between January 2011 and June 2019 were retrospectively reviewed. Data including demographic characteristics, complaints, preoperative serum calcium, phosphorus, and parathyroid hormone levels, preoperative imaging methods, surgical method, localization and size of adenoma, length of hospital stay, and duration and amount of drainage were recorded.

Results: Adenoma was localized in anterior mediastinum in seven patients and in the middle mediastinum in four patients. The mean diameter calculated by taking into account the longest diameter of parathyroid adenoma was $21.1 \mathrm{~mm}$. The mean drainage duration was 3.5 days in two patients undergoing median sternotomy, five days in one patient undergoing thoracotomy, 1.2 days in three patients undergoing video-assisted thoracoscopic surgery, and 0.6 days in five patients undergoing robotic surgery.

Conclusion: Minimally invasive approaches such as videoassisted thoracoscopic surgery and robotic-assisted surgery are safe and effective approaches for excision of mediastinal parathyroid adenoma.
\end{abstract}

Keywords: Mediastinum, minimally invasive surgery, parathyroid adenoma, robotic surgery.

\section{$\ddot{O} \mathrm{Z}$}

Amaç: Bu çalışmada mediastinal paratiroid adenom eksizyonu yapılan hastaların demografik özellikleri, ameliyat öncesi adenom yerleşimi, adenomun büyüklüğü ve yerleşim yerine göre seçilen cerrahi teknikler ve klinik sonuçlar değerlendirildi.

Çalışma planı: Ocak 2011-Haziran 2019 tarihleri arasında kliniğimizde mediastinal paratiroid adenom eksizyonu yapılan toplam 11 hastanın (4 erkek, 7 kadın; ort. yaş 52.6 yıl; dağılım 25-65 yıl) tıbbi kayıtları retrospektif olarak incelendi. Demografik özellikler, şikayetler, ameliyat öncesi serum kalsiyum, fosfor ve parathormon düzeyleri, ameliyat öncesi görüntüleme yöntemleri, cerrahi yöntem, adenomun yerleşim yeri ve büyüklüğü, hastanede kalış süresi ve hastaların drenaj süresi ve miktarı dahil olmak üzere veriler kaydedildi.

Bulgular: Adenom yedi hastada anterior mediastende ve dört hastada orta mediastende yerleşmiş idi. Paratiroid adenomun en uzun çapı dikkate alınarak hesaplanan ortalama çap $21.1 \mathrm{~mm}$ idi. Ortalama drenaj süresi median sternotomi yapılan iki hastada 3.5 gün, torakotomi uygulanan bir hastada beş gün, video yardımlı torakoskopik cerrahi yapılan üç hastada 1.2 gün ve robotik cerrahi yapılan beş hastada 0.6 gün idi.

Sonuç: Video yardımlı torakoskopik cerrahi ve robotik yardımlı cerrahi gibi minimal invaziv yaklaşımlar, mediastinal paratiroid adenom eksizyonunda güvenli ve etkili yaklaşımlardır.

Anahtar sözcükler: Mediastinum, minimal invaziv cerrrahi, paratiroid adenomu, robotik cerrahi. 
Parathyroid adenomas which cause primary hyperparathyroidism are usually located adjacent to the thyroid gland. However, 6 to $16 \%$ of cases have an adenoma in the ectopic localization. ${ }^{[1-3]}$ Mediastinum is one of the rare localizations of the parathyroid adenoma (2\%) and, in such cases, the cervical approach is not appropriate for excision..$^{[1,4]}$ The treatment of the parathyroid adenoma is the complete excision of the hyperfunctioning parathyroid gland.$^{[4]}$

It is quite difficult to distinguish parathyroid adenomas intraoperatively from the surrounding tissues. In the literature, the rate of reexploration after a failed surgery has been reported as 28 to $30 \% .^{[1]}$ Therefore, the correct preoperative localization of the gland establishes the first step in determining the surgical approach.

Parathyroid adenomas are usually excised by the cervical approach, but sternotomy becomes the standard approach when mediastinal localization is the case. However, with a relatively high rate of morbidity, this approach has recently been replaced by minimally invasive approaches such as video-assisted thoracoscopic surgery (VATS) and robot-assisted thoracic surgery (RATS). ${ }^{[5,6]}$

To the best of our knowledge, there are no extensive studies in the literature examining surgical approaches in excision of mediastinal parathyroid adenomas. In this study, we, therefore, aimed to evaluate demographic characteristics, preoperative adenoma localization, surgical techniques selected according to the size and localization of adenomas, and clinical results of patients undergoing mediastinal parathyroid adenoma excision.

\section{PATIENTS AND METHODS}

Medical records of a total of 11 patients (4 males, 7 females; mean age 52.6 years; range, 25 to 65 years) who underwent excision of mediastinal parathyroid adenoma in our clinic between January 2011 and June 2019 were retrospectively reviewed. Demographic characteristics, complaints, preoperative serum calcium, phosphorus, and parathyroid hormone (PTH) levels, preoperative imaging methods, surgical method, localization and sizes of adenomas, length of hospital stay, duration and amount of drainage of the patients were recorded. Most of the cases were detected incidentally. In our series of 11 patients, the symptom of admission was chest pain in three patients. Serum calcium, phosphorus, PTH values and preoperative routine blood tests were also studied in all patients. Serum calcium level was above $10 \mathrm{mg} / \mathrm{dL}$ in all patients. Following the clinical suspicion of mediastinal parathyroid adenoma (MPA), the first diagnostic tool to identify the localization in most patients was ultrasound (US) for thyroid or parathyroid glands. In addition, nine of the patients underwent a scintigraphic imaging from mandible to the xiphoid process. The relationship of the lesion with the surrounding tissues was investigated by thoracic computed tomography (CT) in five patients (in the middle mediastinum in three cases and in the anterior mediastinum in two cases). Positron emission tomography (PET)/CT was performed in three patients, since the preoperative diagnosis was a lung malignancy. A written informed consent was obtained from each patient. The study protocol was approved by the Gülhane Training and Research Hospital Institutional Review Board. The study was conducted in accordance with the principles of the Declaration of Helsinki.

\section{Statistical analysis}

This was a retrospective case series study. Qualitative data were summarized with mean where percentages were used for quantitative data. However, all patients demographic and clinical data were given (Table 1). Clinical results of surgeries performed with VATS and RATS were compared with Mann Whitney $\mathrm{U}$ test. A $p$ value $<0.05$ was considered as statistically significant.

\section{RESULTS}

Of the patients, two had chest pain, one had contraction, and one had fatigue complaints. In one patient, a parathyroid adenoma was detected upon high calcium levels, during the investigation of recurrent nephrolithiasis etiology. Five patients were asymptomatic and high incidental calcium levels were found in routine biochemical analyses (Table 1).

The localization of the parathyroid adenoma and gland were identified by a combination of technetium $99 \mathrm{~m}\left(\mathrm{Tc}^{99 \mathrm{~m}}\right)$ - sestamibi scintigraphy (Figure 1) and US in 10 patients. Scintigraphy was not necessary in one patient, as the diameter of adenoma was larger than $5 \mathrm{~cm}$ (Patient No. 2) and thoracic CT was sufficient for the evaluation (Figure 2). Of all the patients, seven underwent thoracic CT, while two underwent PET/CT.

In one patient (Patient No. 9), on both scintigraphy and US, a mediastinal parathyroid adenoma was suspected. The PET/CT revealed an 18x20-mm nodular lesion in the right posterior lateral aspect of the trachea with fluorodeoxyglucose (FDG) uptake (maximum standard uptake value [SUV $\mathrm{Smax}_{\text {a }}$ : 9.9) (Figure 3). 


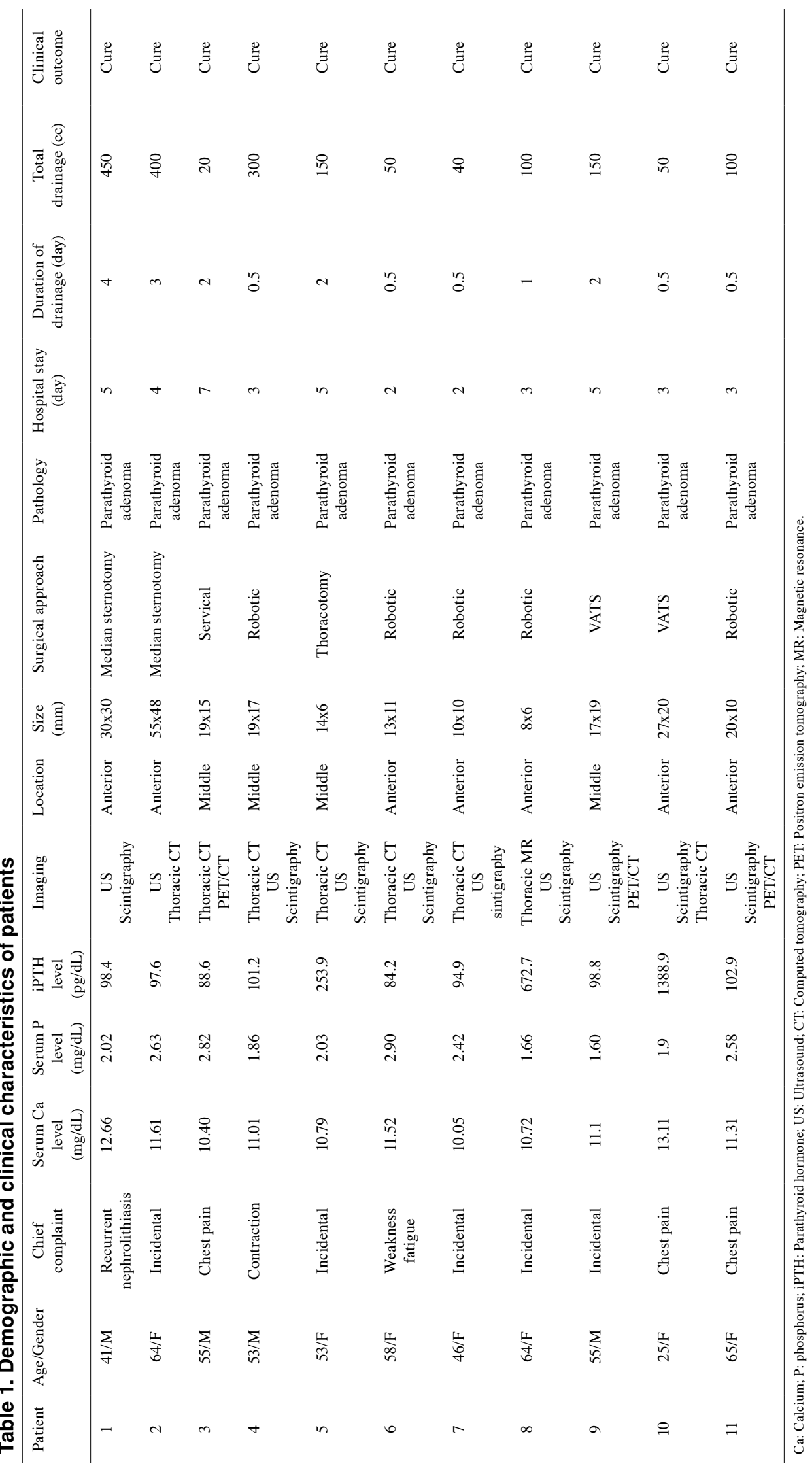




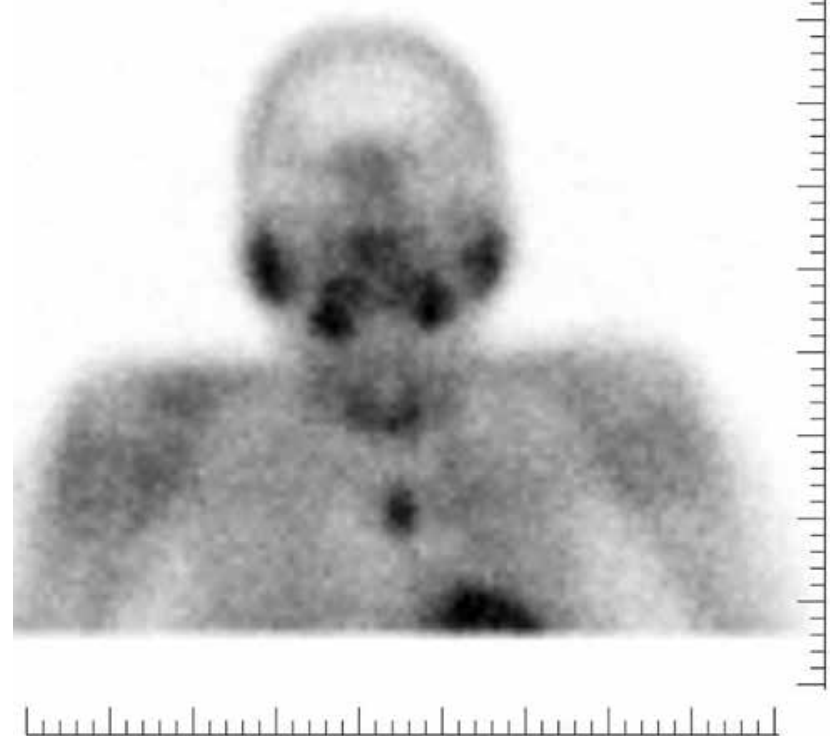

Figure 1. Scintigraphic imaging of a parathyroid adenoma.

In another patient (Patient No. 3), a 37x45-mm mass lesion in the right upper lobe of the lung ( $\mathrm{SUV}_{\max }$ : 11.7) and increased $15 \times 17-\mathrm{mm}$ focal FDG uptake in the lymph node (SUV $\left.\mathrm{V}_{\max }: 22.0\right)$ along with infiltration in the left upper paratracheal region were detected on PET/CT. Since the lesion in the right upper lobe was defined as a squamous cell carcinoma by transthoracic

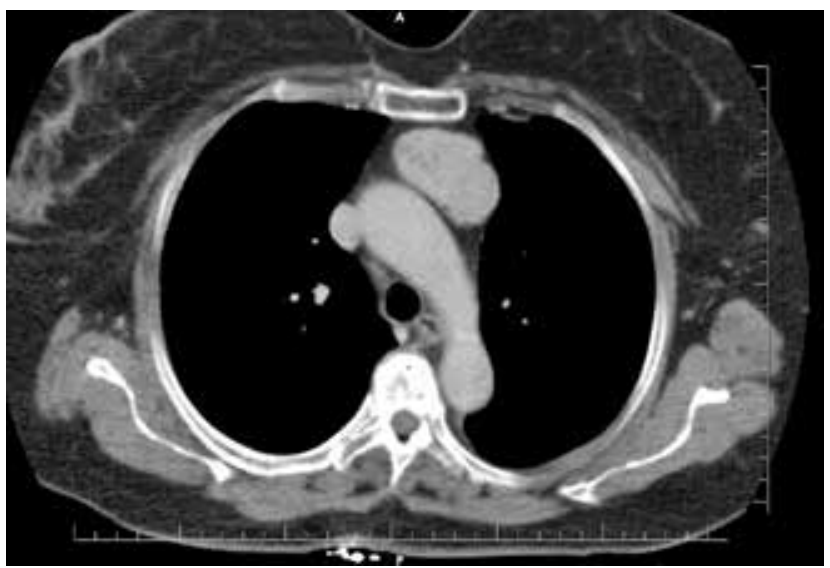

Figure 2. A $55 \times 33 \times 48-\mathrm{mm}$ mass located at anterior mediastinum.

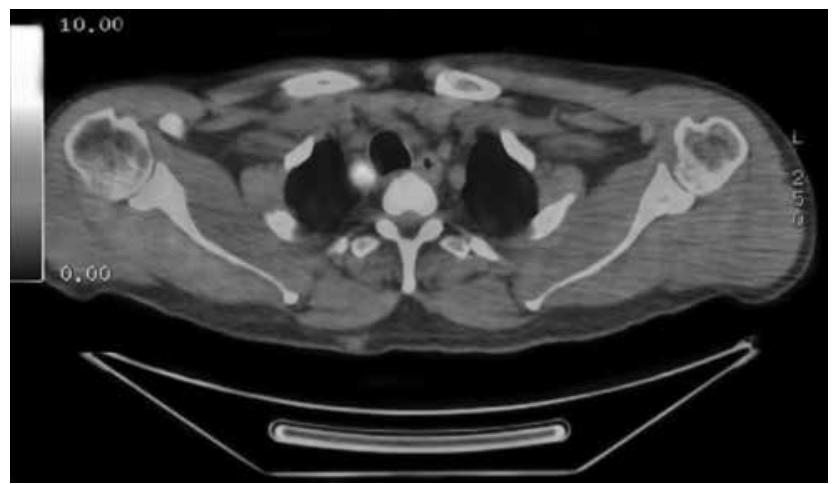

Figure 3. An $18 \times 14 \times 20-\mathrm{mm}$ high-metabolic nodular lesion at right lateral surface of trachea.
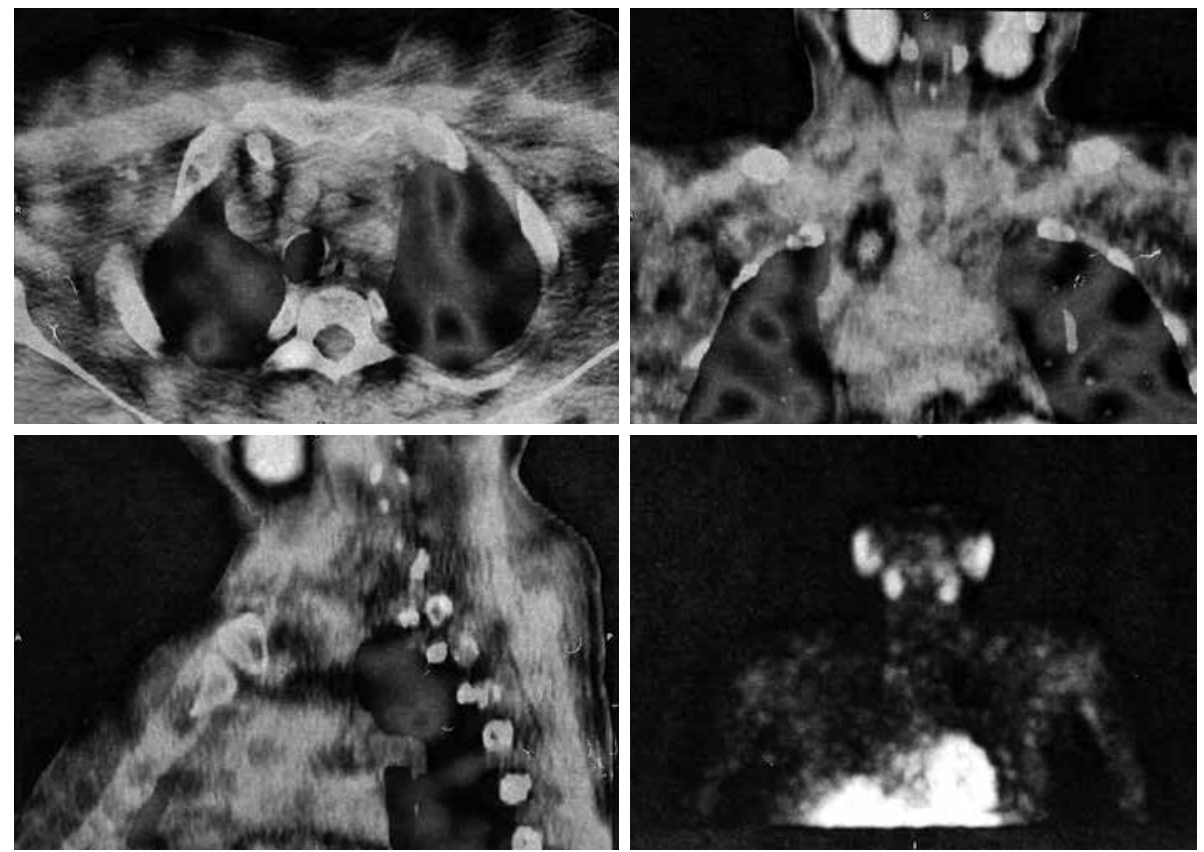

Figure 4. An increased $(15 \times 17 \mathrm{~mm})$ focal fluorodeoxyglucose uptake in lymph node $\left(S V_{\max }\right.$ 22.0) along with infiltration in left upper paratracheal region.

$\mathrm{SUV}_{\max }$ : Maximum standard uptake value. 
biopsy, the patient was evaluated as N3-positive and received chemoradiotherapy. It was remarkable in the control PET/CT that the primary malignant mass lesion had complete metabolic response to treatment, while the lymph node showed resistance ( $\left.S U V_{\max }: 17\right)$ (Figure 4). Therefore, the patient was re-evaluated and lymph node was removed by cervical incision. The frozen section result was compatible with a parathyroid adenoma and the patient underwent right thoracotomy upper bilobectomy for lung carsinom. ${ }^{[7]}$

An adenoma was localized in the anterior mediastinum in seven patients and in the middle mediastinum in four patients. The mean diameter calculated by taking into account the longest diameter of parathyroid adenomas was $21.1 \mathrm{~mm}$. The drainage durations were as follows: two patients who underwent median sternotomy had a mean drainage time of 3.5 days, it was five days for a patient who underwent thoracotomy, 1.2 days for three patients who underwent VATS, and 0.6 days for five patients who underwent RATS. No complications were seen in any of the patients.

\section{DISCUSSION}

Currently, most parathyroid adenomas can be easily excised by cervical approach. Excision of ectopic mediastinal adenomas requires transsternal or transthoracic approach and is the interest of thoracic surgery. Sternotomy and thoracotomy, which were the standard approaches in the past, are morbidityincreasing methods on their own. Russell et al. ${ }^{[8]}$ reported a morbidity rate of $29 \%$ in 38 patients who underwent median sternotomy. Also, in other series, complications such as pleural effusion, subclavian vein thrombosis, recurrent nerve paralysis, chondritis and chylous fistula, and prolonged hospital stay exceeding 10 days have been reported. ${ }^{[9,10]}$

Today, parathyroidectomy with VATS and RATS provides certain advantages such as less postoperative pain, less complications, shorter hospitalization time, shorter time to return to daily activities, and improved cosmetic results. Thoracoscopic approach was first established in 1994 by Prinz et al. ${ }^{[7]}$ and it has become a commonly used method for the excision of mediastinal parathyroid adenomas today. Alesina et al. ${ }^{[1]]}$ reported that the mean operation time was $90 \pm 53 \mathrm{~min}$ in seven patients who underwent thoracoscopy for mediastinal parathyroid adenoma and all procedures were completed thoracoscopically. In a meta-analysis in which 58 thoracoscopic parathyroidectomy cases were examined, the success rate was reported as $98 \%$. In the light of these findings, it can be speculated that thoracoscopic parathyroidectomy is a safe and applicable method. In our study, two patients who underwent excision of parathyroid adenoma with VATS had full resection, and no complications were encountered with excellent cosmetic results.

Over the last two decades, RATS has been introduced in the practice of thoracic surgery. The implementation of the minimally invasive surgery with high technology have surgical tools with the maneuver capacity of a human wrist, filtration of the physiological tremor $(6-\mathrm{Hz}$ motion filter), good dissection capacity in hard-to-access fields, three-dimensional imaging possibility, and $10 \times$ magnification capacity. ${ }^{[5,12,13]}$ The main advantage of RATS is that it provides access to deep and narrow areas through highly maneuverable instruments, where exploration and access are difficult even in open surgeries. Compared to other approaches, RATS is a superior method in the incisions of the highly narrow mediastinal lesions where vital organs, vena cava superior, brachiocephalic vein, phrenic nerves, and vagus nerve are located. ${ }^{[14]}$ However, it cannot be used extensively due to its high cost and inaccessibility. Therefore, the number of surgeons and centers having the opportunity to gain experience is still limited. However, as the competition in the robotics industry gets hotter, this trend may change, as well. ${ }^{[5]}$

The first robot-assisted mediastinal parathyroidectomy was performed by Bodner et al. ${ }^{[15]}$ in 2004 and no detailed series are available yet. To the best of our knowledge, there is no study comparing RATS to other methods. In their series including five cases, Ward et al. ${ }^{[6]}$ reported no morbidity and mortality where they performed RATS parathyroidectomy, and found that calcium and PTH levels decreased effectively. In our study, five patients who underwent robotic mediastinal parathyroid adenoma excision had a mean hospital stay length of 2.6 days, a drainage duration of 0.6 days, and a drainage amount of $116 \mathrm{~mL}$. All our patients achieved complete cure.

In our study, we found no significant difference in the clinical results of surgeries performed with VATS and RATS. However, this may be due to the limited number of patients in our study. In the future, it may be possible to make a healthy comparison as the number of cases undergoing minimally invasive surgery increase. Currently, surgeons should comply with their own and their institutions' experience and the availability of the equipment in deciding which one of the minimally invasive method they would choose. 
Despite all the advantages of minimally invasive surgery, its success still depends on the correct localization of adenoma. It is not easy to differentiate adenoma from the surrounding tissues intraoperatively and, particularly, in small-sized adenomas, exploration is even more difficult. The combined use of US and Technetium (99mTc)-sestamibi scintigraphy preoperatively increases the sensitivity in determining the localization up to $95 \%$. In addition, perioperative frozen section analysis and intraoperative PTH level testing increase the chance of success.

The half-life of PTH in a patient with normal renal functions ranges from 1.5 to $21.5 \mathrm{~min} \cdot{ }^{[16]}$ Achieving at least $50 \%$ reduction in PTH levels preoperatively and after excision indicates a successful operation. ${ }^{[17-19]}$ The PTH monitoring has been also proven to prevent failure in minimally invasive parathyroid surgery and unnecessary reexplorations. ${ }^{[20]}$ However, it should be kept in mind that there may not be a significant decrease in patients with normal or slightly elevated PTH levels.

The success of frozen section analysis has been reported as $99.2 \%$ in differentiating parathyroid tissue from other tissues. ${ }^{[21]}$ However, it should be remembered that the pathologist can distinguish between adenoma and hyperplasia only when all glands are visualized as large and hypercellular.

The method, which stands out in non-surgical approaches, causes ischemia of the tissue by angiographic injection of the contrast material to the vessel which roughly feeds parathyroid adenoma. This method can be attempted in patients who are not suitable for surgery. ${ }^{[22]}$ However, the failure rate of ablation angiography is about $40 \%$ and is not safe enough. In addition, tissue samples cannot be obtained for histopathological examination with this method.

Surgical failure leads the patient to re-do surgeries and may cause morbidity. Therefore, accurate preoperative localization studies should be conducted with precision and the surgical approach for each individual patient should be determined according to these studies. Minimally invasive surgeries, now as standard, should be considered as a priority. However, some tumors may not be still suitable for removal by minimally invasive techniques.

In our series, the mean diameter of parathyroid adenomas was $21.1 \mathrm{~mm}$. Using robotic surgery, we noticed that although the mean diameter was $\leq 2 \mathrm{~cm}$, all of them were resected successfully which could be attributed both to accurate localization studies and to the precise dissection ability of robotic surgery.
In conclusion, minimally invasive approaches such as video-assisted thoracoscopic surgery and robot-assisted thoracic surgery are safe and effective approaches for the excision of mediastinal parathyroid adenomas. Preoperative anatomical localization studies, intraoperative frozen section analysis, and PTH monitoring are the major factors which affect the surgical success.

\section{Acknowledgements}

The authors would like to thank Assoc. Prof. Kuthan Kavaklı, MD and Prof. Sedat Gurkok, MD for their supervision of this study.

\section{Declaration of conflicting interests}

The authors declared no conflicts of interest with respect to the authorship and/or publication of this article.

\section{Funding}

The authors received no financial support for the research and/or authorship of this article.

\section{REFERENCES}

1. Abbas F, Biyabani SR, Memon A, Talati J. Mediastinal parathyroid adenoma causing primary hyperparathyroidism. J Pak Med Assoc 2007;57:93-5.

2. Roy M, Mazeh H, Chen H, Sippel RS. Incidence and localization of ectopic parathyroid adenomas in previously unexplored patients. World J Surg 2013;37:102-6.

3. Phitayakorn $\mathrm{R}$, McHenry $\mathrm{CR}$. Incidence and location of ectopic abnormal parathyroid glands. Am J Surg 2006;191:418-23.

4. Kitada M, Yasuda S, Nana T, Ishibashi K, Hayashi S, Okazaki S. Surgical treatment for mediastinal parathyroid adenoma causing primary hyperparathyroidism. J Cardiothorac Surg 2016;11:44.

5. Van Dessel E, Hendriks JM, Lauwers P, Ysebaert D, Ruyssers $\mathrm{N}$ Jr, Van Schil PE. Mediastinal parathyroidectomy with the da Vinci robot. Innovations 2011;6:262-4.

6. Ward AF, Lee T, Ogilvie JB, Patel KN, Hiotis K, Bizekis $\mathrm{C}$, et al. Robot-assisted complete thymectomy for mediastinal ectopic parathyroid adenomas in primary hyperparathyroidism. J Robot Surg 2017;11:163-9.

7. Okuyucu K, Kavakli K, Ozaydın S, Karahatay S, Karatas O, Doğan D. Parathyroid adenoma upstaging the lung cancer. Ann Nucl Med 2015;29:371-4.

8. Russell CF, Edis AJ, Scholz DA, Sheedy PF, van Heerden JA. Mediastinal parathyroid tumors: experience with 38 tumors requiring mediastinotomy for removal. Ann Surg 1981;193:805-9.

9. Conn JM, Goncalves MA, Mansour KA, McGarity WC. The mediastinal parathyroid. Am Surg 1991;57:62-6.

10. Cupisti K, Dotzenrath C, Simon D, Röher HD, Goretzki PE. Therapy of suspected intrathoracic parathyroid adenomas. Experiences using open transthoracic approach and videoassisted thoracoscopic surgery. Langenbecks Arch Surg 2002;386:488-93. 
11. Alesina PF, Moka D, Mahlstedt J, Walz MK. Thoracoscopic removal of mediastinal hyperfunctioning parathyroid glands: personal experience and review of the literature. World $\mathrm{J}$ Surg 2008;32:224-31.

12. Arora A, Garas G, Tolley N. Robotic Parathyroid Surgery: Current Perspectives and Future Considerations. ORL J Otorhinolaryngol Relat Spec 2018;80:195-203.

13. Ismail M, Maza S, Swierzy M, Tsilimparis N, Rogalla P, Sandrock D, et al. Resection of ectopic mediastinal parathyroid glands with the da Vinci robotic system. Br J Surg 2010;97:337-43.

14. Kavakli K, Gürkök S, Sapmaz E, Karatas O, Gözübüyük A. Robotic approach to benign mediastinal lesions. Turk Gogus Kalp Dama 2016;24:319-24.

15. Bodner J, Wykypiel H, Greiner A, Kirchmayr W, Freund MC, Margreiter R, et al. Early experience with robotassisted surgery for mediastinal masses. Ann Thorac Surg 2004;78:259-65.

16. Noureldine SI, Gooi Z, Tufano RP. Minimally invasive parathyroid surgery. Gland Surg 2015;4:410-9.

17. Irvin GL 3rd, Solorzano CC, Carneiro DM. Quick intraoperative parathyroid hormone assay: surgical adjunct to allow limited parathyroidectomy, improve success rate, and predict outcome. World J Surg 2004;28:1287-92.

18. Chiu B, Sturgeon C, Angelos P. Which intraoperative parathyroid hormone assay criterion best predicts operative success? A study of 352 consecutive patients. Arch Surg 2006;141:483-7.

19. Mazeh $H$, Chen $H$. Intraoperative adjuncts for parathyroid surgery. Expert Rev Endocrinol Metab 2011;6:245-53.

20. Sagan D, Goździuk K. Surgical treatment of mediastinal parathyroid adenoma: rationale for intraoperative parathyroid hormone monitoring. Ann Thorac Surg 2010;89:1750-5.

21. Westra WH, Pritchett DD, Udelsman R. Intraoperative confirmation of parathyroid tissue during parathyroid exploration: a retrospective evaluation of the frozen section. Am J Surg Pathol 1998;22:538-44.

22. Doherty GM, Doppman JL, Miller DL, Gee MS, Marx SJ, Spiegel AM, et al. Results of a multidisciplinary strategy for management of mediastinal parathyroid adenoma as a cause of persistent primary hyperparathyroidism. Ann Surg 1992;215:101-6. 